\title{
Screening of Genotypes against Alternaria Leaf Spot [Alternaria cucumerina (Ellis and Everh.) Elliott] and Anthracnose [Colletotrichum lagenarium (Pass.) Ellis and Halsted] Diseases in Bottle Gourd [Lagenaria siceraria (Mol.) Standl.]
}

\author{
Aishwarya S. Kammar*, M. P. Basavarajappa, R. K. Mesta,
} S. H. Ramangouda and Shashikanth Evoor

Department of Plant Pathology, University of Horticulture Sciences, Bagalkot, India

*Corresponding author

Ke y w o r d s
Bottle gourd,
Alternaria leaf spot,
Anthracnose, Per
cent Disease
Incidence

\section{A B S T R A C T}

Cultivation of resistant genotypes seems to be the best alternative and most economical to keep the activity of the pathogens under control. Thirteen bottle gourd genotypes were evaluated against the leaf spot disease caused by Alternaria cucumerina and anthracnsoe under natural epiphytotic conditions. The genotype Arka Bahar registered lowest PDI (24.87\%) followed by the genotypes Bot G-1 (28.87\%) and Bot G-2 (30.13\%) and BL-4 (30.96\%). Maximum PDI of 45.01 was noticed in the genotype BL10 followed by the genotype BL-5 (41.82) and Bot G-4-1 (39.45). The genotype Arka Bahar registered lowest Per cent Disease Incidence (26.50) for anthracnose followed by the genotype BL-9 (28.20). Maximum Per cent Disease Incidence of 53.24 was noticed in the genotype P cyl L BL-3 followed by the genotype BL-4 (50.00) and Bot G-4-1 (48.09). Therefore the genotype Arka Bahar and BL-9 were found to be moderately resistant to the disease. Genotype Arka Bahar was found to be moderately resistant and remaining genotypes were susceptible to the disease.

\section{Introduction}

Bottle gourd [Lagenaria siceraria (Mol.) Standl.] is one of the important cucurbitaceous vegetable crops, which belongs to the family Cucurbitaceae having the chromosome number $2 \mathrm{n}=22$. It is a warm season crop, monoecious climber and propagated through seeds. In India, it is cultivated in an area of 149 thousand hectare with production of 2458 thousand metric tonnes (Anon, 2017). In Karnataka, bottle gourd is cultivated in an area 
of 0.65 thousand hectare with production of 8.36 thousand metric tonnes and (Anon, 2017). The fruits harvested at mature stage are used for making a wide range of articles of common use, including bowls, bottles, containers and musical instruments (Thamburaj and Singh, 2001). As per nutrient data base of USDA $100 \mathrm{~g}$ of bottle gourd consists water $(96 \%)$, carbohydrate $(2.9 \%)$, protein $(0.2 \%)$, fat $(0.5 \%)$, mineral matter (0.5\%), $20 \mathrm{mg}$ calcium, $10 \mathrm{mg}$ phosphorous, $11 \mathrm{mg}$ of vitamin $\mathrm{C}$ per $100 \mathrm{~g}$ fresh weight and traces of vitamin $\mathrm{A}$ and vitamin $\mathrm{B}$ with a calorific value of 1.2 cal. The crop is affected by various fungal, bacterial and viral diseases. Among them Alternaria leaf spot caused by Alternaria sp. is more destructive and prevalent in major bottle gourd growing areas. Losses caused by them are always considered to be a limiting factor for yield in bottle gourd (Maheshwari et al., 2017). Ill effects of the diseases are observed on foliage as well on fruits (Seebold, 2010). Alternaria leaf blight alone reported to cause $100 \%$ yield loss in cucurbits caused by Alternaria cucumerina (Watt, 2004). Bhargava and Singh (1985) reported that in bottle gourd plant infected by A. cucumerina, initial infection was yellow to brown spots, with yellow hallow.

Mundkur (1937) explained the symptoms of Colletotrichum lagenarium on leaves, stem, fruits, sometimes on the entire seedling and rarely on stem. Layton (1937) reported that the symptoms appeared as small, raised, water soaked areas on the leaves located along the vines near the crown of the plant. The centre of the spot contains saucer shaped fruiting body acervuli. This disease was first described during 1867 on gourd fruits in Italy. The bottle gourd anthracnose was first reported by Gardner in 1918 from USA, and was described as Colletotrichum lagenarium (Pass.) Ell. and Halst. In India it was first reported by Mundkur on long melon (Cucumis melo var. utilissimus Roxb.) and bottle gourd
(Lagenaria siceraria Mol. Standl) to be very serious near Ferozepur in Punjab in 1937. The disease is reported to occur severely in USA, Hungary, Netherlands, Canada, India (Madaan and Grover, 1978) and Japan (Kobayashi et al., 1998).

Chemical control is expensive and adversely affects the environment. The residual effect of fungicides causes health hazards to the human being. Breeding for disease resistance has been an effective, economical and practical method of disease control. Cultivation of resistant genotypes seems to be the best alternative and most economical to keep the activity of the pathogens under control. In all crop improvement programmes, growing of resistant varieties have been found to be appropriate choice to combat the disease. So far, the information available on the availability of resistant sources is scanty, thus there exists a need to identify the resistant sources. Keeping all these points in view, the present research work was undertaken on screening of genotypes against Alternaria leaf spot and anthracnose in bottle gourd.

\section{Materials and Methods}

A field experiment was conducted at Haveli Farm, College of Horticulture, Bagalkot to find out the source of resistance for leaf spot disease in bottle gourd. A total of 13 genotypes were collected from Dr. Shashikanth Evoor, Assistant Professor, Department of Vegetable Science, College of Horticulture, Bagalkot. Genotypes were sown with a spacing of $3 \times 0.9 \mathrm{~m}$. Observations were recorded on severity of the Alternaria leaf spot disease at a week's interval and converted in to PDI by following 0 to 5 scale given by Mayee and Datar (1986). The highest score indicating more severity of the disease.

Observations were made on Per cent Disease Incidence for anthracnose disease by counting 
total number of healthy and infected fruits in each treatment and per cent disease incidence was calculated by using following formulae

Per cent Disease Incidence

No. of infected fruits

in a treatment

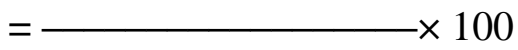

Total number of fruits

in a treatment

Observations were recorded on severity of the anthracnose disease at regular interval and converted in to Per cent Disease Incidence by following 0 to 5 scale given by Singh et al., 1993.

\section{Results and Discussion}

Thirteen bottle gourd genotypes were evaluated against the leaf spot disease caused by $A$. cucumerina under natural epiphytotic conditions.

The results presented in Table 1 indicated that the genotype Arka Bahar registered lowest PDI (24.87) followed by the genotypes Bot G1 (28.87) and Bot G-2 (30.13) and BL-4 (30.96). Maximum PDI of 45.01 was noticed in the genotype BL-10 followed by the genotype BL-5 (41.82) and Bot G-4-1 (39.45).

Based on the reaction of the different genotypes to the disease, it was observed that none of the varieties were resistant. However, the genotype Arka Bahar was found to be moderately resistant to Alternaria leaf spot. These results are in agreement with the Maheshwari et al., (2015), where Arka Bahar showed moderately resistant reaction with 4.87-8.62 per cent disease severity.

Sinha (2014) screened ten varieties against Alternaria leaf spot disease in cabbage, concluded that one variety i.e. Pusa Mukta was found moderately resistant reaction (MR) with minimum disease intensity of 9.8 per cent. Yousuf (2009) screened twenty cucumber cultivars against Alternaria leaf spot disease, only four cultivars Pusa Sanyug, Green Express and Marketer-76 were rated as tolerant (rating 1-10\%). Six cultivars viz., Sweet Delight, CH-20, Priya, Hybrid-5, S-5 and Poinsette were moderately tolerant (11$25 \%$ ). Remaining cultivars were moderately susceptible and susceptible.

Thirteen genotypes were evaluated against the anthracnose disease caused by $C$. lagenarium under natural epiphytotic conditions. Table 2, depicts Per cent Disease Incidence of anthracnose disease on bottle gourd fruits was recorded. The results indicated that that the genotype Arka Bahar registered lowest Per cent Disease Incidence $(26.50 \%$ ) followed by the genotype BL-9 (28.20\%). Maximum Per cent Disease Incidence of 53.24 was noticed in the genotype $\mathrm{P}$ cyl L BL-3 followed by the genotype BL-4 (50.00\%) and Bot G-4-1 $(48.09 \%)$.

Based on the reaction of the different genotypes to the diseases, it was observed that none of the varieties were resistant. However, the genotype Arka Bahar and BL-9 were found to be moderately resistant to the anthracnose disease.

Screening of germplasm resistance/ susceptible to anthracnose in bottle gourd was also done by the earlier workers. Chauhan (2002) evaluated 22 genotypes of bottle gourd against anthracnose disease. GH-3, GH-9 and Winter Ghiya-1 recorded resistant reaction with 1-5 per cent disease intensity. Remaining showed moderately susceptible, and susceptible reaction. Chauhan and Bhatia (2013) screened 22 genotypes of bottle gourd against anthracnose disease under natural and artificial inoculation condition (Table 3 and 4). 
Table.1 Details of the disease reaction for Alternaria leaf spot disease

\begin{tabular}{|c|c|c|}
\hline Reaction Category & Disease severity (\%) & Grade (0-5) \\
\hline Immune & 0 & 0 \\
\hline Resistant & $1-10$ & 1 \\
\hline Moderately resistant & $11-25$ & 2 \\
\hline Moderately susceptible & $26-50$ & 3 \\
\hline Susceptible & $51-75$ & 4 \\
\hline Highly Susceptible & $76-100$ & 5 \\
\hline
\end{tabular}

Table.2 Details of disease reaction for anthracnose disease

\begin{tabular}{|c|c|c|}
\hline Reaction Category & Disease incidence (\%) & Grade (0-5) \\
\hline Immune & 0 & 0 \\
\hline Highly Resistant & $0.1-5.0$ & 1 \\
\hline Resistant & $5.1-10.0$ & 2 \\
\hline Moderately resistant & $10.1-50.0$ & 3 \\
\hline Susceptible & $51.1-90.0$ & 4 \\
\hline Highly Susceptible & $>90.0$ & 5 \\
\hline
\end{tabular}

Table.3 Screening of bottle gourd genotypes for resistance to Alternaria leaf spot disease

\begin{tabular}{|c|c|c|c|c|}
\hline \multirow{2}{*}{$\begin{array}{c}\text { Sl. } \\
\text { No. }\end{array}$} & \multirow[t]{2}{*}{ Genotype } & \multicolumn{3}{|c|}{ Alternaria leaf spot disease } \\
\hline & & $\begin{array}{c}\text { Per cent } \\
\text { Disease } \\
\text { Index }\end{array}$ & $\begin{array}{c}\text { Maximum } \\
\text { Disease } \\
\text { Grade }\end{array}$ & Disease reaction \\
\hline 1 & Bot G-1 & 28.87 & 3 & Moderately susceptible \\
\hline 2 & Bot G-2 & 30.13 & 3 & Moderately susceptible \\
\hline 3 & P cyl L BL-3 & 37.29 & 3 & Moderately Susceptible \\
\hline 4 & BL-4 & 30.96 & 3 & Moderately susceptible \\
\hline 5 & Bot G-4-1 & 39.45 & 4 & Susceptible \\
\hline 6 & BL-5 & 41.82 & 4 & Susceptible \\
\hline 7 & Bot G-6 & 32.04 & 3 & Moderately susceptible \\
\hline 8 & Bot G-6-2 & 36.69 & 3 & Moderately Susceptible \\
\hline 9 & Bot G-7-1 & 31.97 & 3 & Moderately susceptible \\
\hline 10 & BL-9 & 38.05 & 3 & Moderately susceptible \\
\hline 11 & BL-10 & 45.10 & 4 & Susceptible \\
\hline 12 & Arka Bahar & 24.87 & 2 & Moderately resistant \\
\hline 13 & $\begin{array}{l}\text { Kolkata } \\
\text { Collection }\end{array}$ & 33.49 & 3 & Moderately susceptible \\
\hline & S. Em \pm & 1.11 & & \\
\hline & CD@ $0 \%$ & 3.40 & & \\
\hline
\end{tabular}


Table.4 Screening of bottle gourd genotypes for resistance to anthracnose disease

\begin{tabular}{|c|c|c|c|c|}
\hline $\begin{array}{c}\text { SI } \\
\text { No. }\end{array}$ & Genotype & $\begin{array}{c}\text { Per cent Disease } \\
\text { Incidence }\end{array}$ & $\begin{array}{c}\text { Maximum } \\
\text { Disease Grade }\end{array}$ & Disease reaction \\
\hline $\mathbf{1}$ & Bot G-1 & 28.87 & 4 & Susceptible \\
\hline $\mathbf{2}$ & Bot G-2 & 30.13 & 4 & Susceptible \\
\hline $\mathbf{3}$ & P cyl L BL-3 & 37.29 & 4 & Susceptible \\
\hline $\mathbf{4}$ & BL-4 & 30.96 & 4 & Susceptible \\
\hline $\mathbf{5}$ & Bot G-4-1 & 39.45 & 4 & Susceptible \\
\hline $\mathbf{6}$ & BL-5 & 41.82 & 4 & Susceptible \\
\hline $\mathbf{7}$ & Bot G-6 & 32.04 & 4 & Susceptible \\
\hline $\mathbf{8}$ & Bot G-6-2 & 36.69 & 4 & Susceptible \\
\hline $\mathbf{9}$ & Bot G-7-1 & 31.97 & 4 & Susceptible \\
\hline $\mathbf{1 0}$ & BL-9 & 38.05 & 3 & Moderately resistant \\
\hline $\mathbf{1 1}$ & BL-10 & 45.10 & 4 & Susceptible \\
\hline $\mathbf{1 2}$ & Arka Bahar & 24.87 & 3 & Moderately resistant \\
\hline $\mathbf{1 3}$ & Kolkata Collection & 33.49 & 4 & Susceptible \\
\hline & S. Em \pm & 1.11 & & \\
\hline & CD @ 5\% & 3.40 & & \\
\hline
\end{tabular}

In natural conditions four genotypes viz. GH3, GH-9, GH-10 and GH-25, under artificial inoculation conditions, three genotypes viz. GH- 9, GH-3and Winter ghiya-1 were found resistant with 1-5 per cent disease intensity. Ankit kumar et al., (2016) screened 24 cultivars/germplasm against anthracnose of bottle gourd.

Three genotype viz. K-92420, GH-3 and GH11 were found resistant with $0-5$ per cent disease intensity and remaining genotypes were moderately susceptible and susceptible to the disease.

The genotype Arka Bahar registered lowest PDI (24.87) followed by the genotypes Bot G1 (28.87) and Bot G-2 (30.96) and BL-4 (30.96). Maximum PDI of 45.01 was noticed in the genotype BL-10 followed by the genotype BL-5 (41.82) and Bot G-4-1 (39.45). Therefore the genotype Arka Bahar was found to be moderately resistant to both the diseases. The genotype BL-9 was found to be moderately resistant to anthracnose disease.

\section{References}

Ankit kumar, Singh, N., Raj, K., Khanna, A. and Singh, H., 2016, Prevalence and evaluation of different germplasm lines /cultivars against anthracnose of bottlegourd under artificial inoculation condition Int. J. Curr. Microbi.App. Sci.(3): 231-239

Anonymous, 2017, Horticultural statistics at a glance, p. 286

Bhargava, A. K. and Singh, R. D., 1985, Comparative study of Alternaria blight, losses an causal organisms of cucurbits in Rajasthan. Ind. J. Mycol. \& Plant Pathol.,15: 150-154

Chauhan, R. S. and Bhatia, J. N., 2013, Screening of bottle gourd genotypes against anthracnose disease under natural as well as artificial epiphytotic conditions. Plant Dis. Res., 28(1): 9293

Chauhan, R. S., 2002, Studies on anthracnose disease of bottle gourd caused by Colletotrichum lagenarium (Pass.) Ell. 
and Halst. Ph.D. Thesis, HAU., Hissar Gardner, M. W., 1918, Anthracnose of cucurbits. USDA. Bulletin., 721: 1-68

Kobayashi, Y., Kimishima, E. and Tokei, R.,1998, Anthracnose of pumpkin caused by Colletotrichum orbiculare (Berk. And Mnt.) Arx intercepted in important plant quarantine in Japan. Res. Bull. Plant Prot., 34: 55-58.

Madaan, R. L. and Grover, R. K., 1978, Some pathological studies on anthracnose affecting bottle gourd. Indian Phytopathol., 30: 392-398

Maheshwari, S. K., Choudhary, B. R., Sharma, B. D. and Saroj, P.L., 2017, Management of Alternaria leaf blight of bottle gourd in West Eastern Rajasthan. Indian J. Curr. Microbial. App. Sci., 6(6): 1272-1277

Maheshwari, S.K., Choudhary, B.R. and Singh. D., 2015, Field evaluation of bottle gourd genotypes for resistance against Alternaria blight in western Rajasthan. Vegetos, 28 (3): 103-105
Mayee, C. D. and Datar, V. V., 1986, Pathometry. Technical Bulletin. Marathwada Agric. Univ. Parbhani, India, Pp 144.

Mundkur, B.B., 1937, Anthracnose of cucurbits in the Punjab. Curr. Sci., 12: 647.

Singh, H. P., Kaur, S. and Singh, J., 1993. Determination of infection in fruit rot (Colletotrichum capsici) of chilli (Capsicum annum). Indian. J. Agric. Sci. 63: 310-312

Thamburaj, S. and Singh, N., 2001, Cucurbitaceous vegetables. Textbook of Vegetables, Tub crops and Spices., p. 271-319.

Wheeler, B.E., 1969, An Introduction to Plant Diseases. Jhon Wiley and Sons Ltd., London, UK. p. 301.

Yousuf, S., 2009, Studies on Fungal Foliar Diseases of Cucumber (Cucumis sativus L.) in Kashmir Valley. Ph.D. Thesis, Sher-e Kashmir Univ. Agric. Sci. and tech., Kashmir, India

\section{How to cite this article:}

Aishwarya S. Kammar, M. P. Basavarajappa, R. K. Mesta, S. H. Ramangouda and Shashikanth Evoor. 2019. Screening of Genotypes against Alternaria Leaf Spot [Alternaria cucumerina (Ellis and Everh.) Elliott] and Anthracnose [Colletotrichum lagenarium (Pass.) Ellis and Halsted] Diseases in Bottle Gourd [Lagenaria siceraria (Mol.) Standl.]. Int.J.Curr.Microbiol.App.Sci. 8(12): 71-76. doi: https://doi.org/10.20546/ijcmas.2019.812.011 